https://doi.org/10.52058/2708-7530-2021-4(10)-42-49

Іванов Андрій Вікторович аспірант кафедри публічного управління та адміністрування Інституту підготовки кадрів державної служби зайнятості України, вул. Нововокзальна, 17, м. Київ, 03038, тел.: (044) 239-07-99, e-mail: naykipk@ukr.net, https://orcid.org/0000-0002-8360-691X

\title{
ДІЯЛЬНІСТЬ ЦЕНТРІВ РОЗВИТКУ ПІДПРИЕМНИЦТВА ЯК СКЛАДОВА МЕХАНІЗМУ РЕАЛІЗАЦІї ДЕРЖАВНОЇ ПОЛІТИКИ ЩОДО ПОДОЛАННЯ БЕЗРОБІТТЯ
}

Анотація. У статті здійснено дослідження діяльності центрів розвитку підприємництва як складової механізму реалізації державної політики щодо подолання безробіття. Розглянуто нормативно-правове поле, що передбачає створення таких центрів. Охарактеризовано мету створення центрів розвитку підприємництва Державною службою зайнятості. Сприяння зайнятості для організації безробітними підприємницької діяльності - важливий елемент механізму реалізації державної політики щодо подолання безробіття. Державна політика зайнятості впливає на формування відповідних умов для повноцінного функціонування об'єкта розвитку, зокрема через зростання добробуту i підвищення якості життя населення, забезпечення позитивних структурних зрушень в економіці, підвищення ऑii конкурентних переваг, як основи для збалансованого зростання стандартів та показників соціально-економічного розвитку.

Визначено, що центри розвитку підприємництва є об'єктами інфраструктури підтримки малого і середнього підприємництва. Виділено основні функції центрів розвитку підприємництва. Визначено основні завдання центрів розвитку підприємництва до яких віднесено розбудову ефективної інформаційної інфраструктури підтримки підприємництва; підвищення конкурентоспроможності підприємців; надання якісної інформаційно-консультаційної допомоги підприємцям; мотивація людей до започаткування власної справи. Узагальнено заходи, які вони здійснюють $з$ метою реалізації своїх завдань. Оглянуто такий напрямок діяльності центрів розвитку підприємництва, як консультування щодо програми сприяння зайнятості для організації безробітними підприємницької діяльності яка реалізується Державною службою зайнятості на постійній основі у вигляді одноразової виплати допомоги по безробіттю для організації підприємницької діяльності. Тобто дані центри можуть надавати консультації 
щодо сутності активної програми сприяння зайнятості - одноразової виплати допомоги по безробіттю для організації безробітними підприємницької діяльності, яку протягом багатьох років ефективно реалізує Державна служба зайнятості. Активна програма сприяння зайнятості для організації безробітними підприємницької діяльності реалізується на постійній основі. Встановлено, що поряд 3 розвитком об’єктів інфраструктури підтримки підприємництва, таких як центри розвитку підприємництва Державної служби зайнятості, стійке подолання безробіття можливе лише в комплексі з розвитком економіки та ефективними економічними реформами.

Ключові слова: механізм, політика зайнятості, безробіття, підприємництво, служба зайнятості, держава.

Ivanov Andrii Viktorovych Postgraduate student of the Department of Public Administration and Administration of the Institute for the Ukrainian state employment service training institute, Novovokzalna St., 17, Kyiv, 03038, tel .: (044) 239-07-99, email: naykipk@ukr.net, https://orcid.org/0000-0002-8360-691X

\title{
ACTIVITIES OF BUSINESS DEVELOPMENT CENTERS AS A COMPONENT OF A MECHANISM FOR IMPLEMENTING A STATE POLICY TO OVERCOME UNEMPLOYMENT
}

\begin{abstract}
The activities of enterprise development centers as a component of the mechanism for implementing a state policy to overcome unemployment was investigate in the article. The regulatory field, which involves the creation of such centers, is considered. The purpose of creating centers of entrepreneurship development by the State Employment Service was characterize. Promoting employment for the organization of unemployed entrepreneurship - an important element of the mechanism for implementing the state policy to overcome unemployment. The state policy of employment affects the formation of appropriate conditions for the full functioning of the object of development, in particular due to the growth of well-being and improving the quality of life of the population, ensuring positive structural changes in the economy, increase its competitive advantages, as the basis for balanced growth of standards and indicators of socio-economic development.

It is determined that entrepreneurship development centers are objects of small and medium-sized enterprise infrastructure. The main functions of enterprise development centers were highlights. The main tasks of enterprise development centers are determined to which the development of an effective information infrastructure support for entrepreneurship is attracted; improving the competitiveness of entrepreneurs; provision of high-quality information and consulting assistance to entrepreneurs;
\end{abstract}


Motivation of people to start their own business. Generalities that they were carry out in order to realize their tasks. Such a direction of activity of enterprise development centers, such as advising on employment promotion program to organize unemployed entrepreneurship, was being implemented by the State Employment Service on a permanent basis in the form of a one-time payment of unemployment benefits for the organization of entrepreneurial activity. That is, these centers can provide consultations on the essence of an active employment assistance program - a one-time unemployment benefit to organize unemployed entrepreneurship, which for many years effectively implements the State Employment Service. The active employment promotion program for the organization of unemployed entrepreneurship was realize on a permanent basis. It has been established that along with the development of entrepreneurship support facilities, such as the Center for Entrepreneurship of the State Employment Service, sustainable unemployment is possible only in the development of economics and effective economic reforms.

Keywords: mechanism, employment policy, unemployment, entrepreneurship, employment service, state.

Постановка проблеми. Державна політика забезпечення зайнятості населення - це дієвий інструмент сприяння ефективному використанню трудового потенціалу та забезпечення населення від безробіття, а також рівних можливостей населення у реалізації конституційних прав на працю, що допомагає узгодженню інтересів всіх суб'єктів трудових та інших відносин у сфері працевлаштування.

Щодо напрямів удосконалення державного управління зайнятістю населення існує ціла низка поглядів. Так, зокрема, Г.О. Вдовіна вказує, що «пріоритетним напрямом удосконалення державного управління зайнятістю населення $\epsilon$ глибокий аналіз стану зайнятості, який має розглядатися не як чисто соціальний феномен, що зумовлює інтерес тільки 3 позиції масштабів безробіття, його професійних аспектів, а бути значно глибшим, адже структурна криза економіки $є$ й кризою структури зайнятості, що склалася в народному господарстві країни» [1]. Погодимося також 3 В.М. Тригубенко, що «нормативно-правове забезпечення реалізації державної політики зайнятості населення повинно включати: використання рекомендацій Міжнародної організації праці; урахування національних особливостей функціонування ринку праці» [2].

Сприяння зайнятості для організації безробітними підприємницької діяльності - важливий елемент механізму реалізації державної політики щодо подолання безробіття. Таким чином, враховуючи вищевикладене, актуалізується потреба дослідження діяльності центрів розвитку підприємництва як складової механізму реалізації державної політики щодо подолання безробіття. 
Аналіз останніх досліджень і публікацій. Дослідженням питання розробки та реалізації державної політики щодо подолання безробіття що спрямована на підтримку підприємництва в Україні займалися такі вчені як Н. Балдич, М. Булавинець, Є.Майовець, С.Побігун, Л.Сімків, Н. Ходько, Л. Чорній, О. Яковенко О. Яйченя, І. Яців та ін. Проте, комплексні дослідження саме діяльності центрів розвитку підприємництва не здійснювалися.

Мета статті - здійснити дослідження діяльності центрів розвитку підприємництва як складової механізму реалізації державної політики щодо подолання безробіття.

Виклад основного матеріалу. Механізм реалізації державної політики щодо подолання безробіття - це сукупність заходів, що спрямовані на покращення якісних характеристик робочої сили, кількісне та якісне зростання пропозиції робочих місць. Як зазначає Л.Д. Яценко, «найважливішою умовою для розширення можливостей працевлаштування $\epsilon$ створення сприятливого середовища для сталого розвитку підприємництва. При цьому варто адаптувати позитивний досвід країн $\mathrm{CC}$, пов'язаний з підтримкою підприємництва шляхом надання консультаційних послуг у поєднанні iз застосуванням гнучкого механізму податкових пільг; активізацією організаційних та фінансовоекономічних механізмів цільового та пільгового кредитування інвестиційних проектів; розробкою і застосуванням системи дотацій на створення нових робочих місць; наданням субсидій, у тому числі регіональних, на створення нових підприємств та робочих місць, на працевлаштування безробітних, насамперед, iз числа соціально вразливих груп населення; створенням бізнес інкубаторів» [3].

На даний час в багатьох країнах світу функціонує значна кількість інституцій підтримки малого та середнього підприємництва, що належать як до державного, так i до приватного секторів. Як зазначається в Програмі «Лідерство в економічному врядуванні» та враховуючи зарубіжний досвід варто зауважити, що «досить ефективним є створення інституцій підтримки малого та середнього підприємництва саме органами публічної влади - як центрального, так i регіонального та місцевого рівнів» [4].

Законом України «Про розвиток та державну підтримку малого і середнього підприємництва в Україні» визначено правові та економічні засади державної політики у сфері підтримки та розвитку малого і середнього підприємництва [5]. Центри розвитку підприємництва Державної служби зайнятості можна віднести до об'єктів інфраструктури підтримки малого і середнього підприємництва. Це певною мірою узгоджується зі статтею 14 названого вище Закону, в якій значиться, що «до об’єктів інфраструктури підтримки малого і середнього підприємництва належать бізнес-центри, бізнес-інкубатори, інноваційні бізнесінкубатори, науково-технологічні центри, центри трансферу технологій, фонди 
підтримки малого підприємництва, лізингові компанії, консультативні центри, інші підприємства, установи та організації, основним завданням яких є сприяння розвитку малого і середнього підприємництва» [5].

До того ж цей підхід знайшов відображення і в інших нормативно-правових актах, які були розроблені переважною своєю більшістю в минулій перспективі до 2020 року. Так, метою Національної програми сприяння розвитку малого підприємництва в Україні від 21.12.2000 року № 2157-III у напрямі формування розвинутої інфраструктури малого підприємництва було передбачено створення «системи інформаційного та консультаційного обслуговування малого підприємництва, спеціалізованих фірм, що надають послуги малим підприємствам (бухгалтерські та аудиторські фірми, рекламні агентства тощо); бізнес-центрів та центрів розвитку малих підприємств, бізнес-інкубаторів, виробничих та технологічних парків; навчальних центрів 3 підготовки та перепідготовки спеціалістів для роботи на малих підприємствах, формування економічних знань i набуття практичних навичок роботи в умовах ринкової економіки; системи підготовки підприємців-початківців, підготовки та підвищення кваліфікації управлінських кадрів сфери підприємництва та державних службовців з основ підприємницької діяльності» [6].

Необхідність створення таких центрів закладалася також Стратегією розвитку малого і середнього підприємництва в Україні на період до 2020 року. Зокрема, даний документ конкретизує потребу «у центрах підтримки підприємців-початківців для надання їм допомоги стосовно реєстрації, подання звітності та консультацій, а також супроводження протягом всього часу існування підприємства» [7]. Проте дані нормативні акти вимагають актуалізації, починаючи уже з наступного 2021 року.

Таке спрямування реалізації політики зайнятості в державі щодо центрів розвитку підприємництва знайшло відображення у внутрішніх документах Центру Зайнятості. Так, Положенням про державну службу зайнятості від 14.06.2019 №945 визначено, що до основних завдань Служби зайнятості віднесено «сприяння громадянам в організації підприємницької діяльності, зокрема шляхом надання індивідуальних та групових консультацій» (п.п.6, п.2) [8]. Тому виходячи з даного положення можна стверджувати, що метою відкриття центрів розвитку підприємництва Державною службою зайнятості $\epsilon$ створення нових робочих місць через функціонування середовища підтримки підприємництва органами місцевої виконавчої влади. Це уже частково здійснюється через підписання багатосторонніх угод про співпрацю між районними державними адміністраціями, райрадами, центрами зайнятості на місцях. У таких угодах передбачається дане співробітництво та узгодження дій місцевих органів влади.

Виходячи 3 вищевикладеного можна визначити такі основні завдання 
центрів розвитку підприємництва: розбудова ефективної інформаційної інфраструктури підтримки підприємництва; підвищення конкурентоспроможності підприємців; надання якісної інформаційно-консультаційної допомоги підприємцям; мотивація людей до започаткування власної справи.

До основних функцій Центрів розвитку підприємництва слід віднести, на погляд служби зайнятості «можливість в отриманні консультації в «одному місці» 3 таких питань як: державна реєстрації суб’єктів господарювання; податкове законодавство, ліцензування, дозвільні процедури в бізнесі; щодо оформлення документів щодо купівлі (оренди) земельних ділянок та приміщень для провадження підприємницької діяльності; це відкриття рахунків у банківських установах; підбір та конкурентний відбір персоналу; оформлення трудових відносин; фінансова підтримка (щодо одноразової виплати допомоги по безробіттю для організації підприємницької діяльності; отримання банківських кредитів; іншої фінансової допомоги)» [9].

3 метою реалізації своїх функцій центри можуть здійснювати такі заходи як: тематичні семінари і тренінги; консультації щодо особливостей започаткування власної справи; тестування на предмет успішності в сфері підприємництва; перевірка бізнес-планів на реалістичність; майстер-класи і тренінги від успішних підприємців (менторів), в тому числі 3 проблемних питань ведення підприємницької діяльності; послуги 3 підбору i конкурентного відбору персоналу; створення в соціальній мережі Фейсбук групи учасників Центрів розвитку підприємництва.

Важливим напрямком діяльності центрів мають стати також консультування щодо одноразової виплати допомоги по безробіттю для організації підприємницької діяльності. Тобто дані центри можуть надавати консультації щодо сутності активної програми сприяння зайнятості - одноразової виплати допомоги по безробіттю для організації безробітними підприємницької діяльності, яку протягом багатьох років ефективно реалізує Державна служба зайнятості. Активна програма сприяння зайнятості для організації безробітними підприємницької діяльності реалізується на постійній основі. У бюджеті Фонду загальнообов'язкового державного соціального страхування України на випадок безробіття на 2020 рік на цю активну програму підтримки безробітних були передбачені видатки в розмірі 386 млн гривень проти 82,2 млн у 2019 році (зростання в 4,7 разів) [10]. Нажаль у 2021 році заплановане згортання таких програм через економічну кризу як в Україні, так і в світі, що першочергово пов'язано 3 поширенням вірусу COVID-19. Хоча така практика має продовжуватися, оскільки «за сприяння служби зайнятості щороку підприємцями стають тисячі колишніх безробітних. Так, протягом 2019 року власну справу за сприяння служби зайнятості започаткували 2,4 тис. осіб, а цього року в планах 
служби - допомогти у започаткуванні власного бізнесу вже 8,5 тис. безробітним, що в 3,6 разів більше. Найчастіше колишні безробітні відкривають свій бізнес у сфері торгівлі, професійної та наукової діяльності, ремонту побутової техніки, а також у переробній промисловості та сільському господарстві» [9].

Висновки. Отже, питання подолання безробіття не можливо вирішити лише через ефективну політику регулювання ринку праці, що $є$ лише елементом державної політики щодо подолання безробіття. Стійке подолання безробіття можливе лише через розвиток економіки та ефективні економічні реформи, адже сучасна фінансово-кредитна i податкова політика в галузі підприємництва виконує далеко не стимулюючу функцію, а лише затримує розвиток підприємницької діяльності в Україні. Тому потрібно враховувати, що центри розвитку підприємництва - це крок до реформування служби зайнятості в сервісну соціальну службу, що має на меті оперативне реагування на потреби ринку праці.

\section{Jimepamypa:}

1. Вдовіна Г. О. Аналіз ринку праці: пропозиція та попит на неї. Л. : Вид. ЛНУ імені Івана Франка, 2011. 145 с.

2. Тригубенко В.М. Адімінстративно-правові засади реалізації державної політики у сфері зайнятості населення. авреф. дис. к.ю.н.: 12.00.07. Дніпро. 2020. 22c. URL: https://dduvs.in.ua/wpcontent/uploads/files/Structure/science/rada31/a2.pdf (дата звернення 29.10.2020).

3. Яценко Л.Д. Щодо пріоритетів політики зниження безробіття в Україні. Національний інститут стратегічних досліджень. 2018. URL: http://old2.niss.gov.ua/content/articles/files/1_ Zapiska-bezrobittya-YAtsenko-22_12_18-9b518.pdf (дата звернення 29.10.2020).

4. Каталог інституцій: Програма «Лідерство в економічному врядуванні» 2014 - 2017. URL: http://www.lev.org.ua/ua/institutions.html?page=8\&per-page $=15$

5. Закон України «Про розвиток та державну підтримку малого i середнього підприємництва в Україні» від 22.03.2012 № 4618-VI. URL: https://zakon.rada.gov.ua/ laws/show/4618-17.

6. Закон України «Про національну програму сприяння розвитку малого підприємництва в Україні» від 21.12.2000 року № 2157-III. URL: https://zakon.rada.gov.ua/laws/show/2157-14\#Text

7. Стратегія розвитку малого і середнього підприємництва в Україні на період до 2020 року: розпорядження Кабінету Міністрів України від 24 травня 2017 р. № 504-p.URL: https://zakon.rada.gov.ua/laws/show/504-2017-p

8. Наказ Міністерства соціальної політики України «Про затвердження Положення про державну службу зайнятості» від 14.06.2019 №945. URL: https://zakon.rada.gov.ua/laws/show/ z0733-19\#Text

9. Державний центр зайнятості. Офіційний сайт. URL: https://www.dcz.gov.ua/

10. Власний бізнес за сприяння служби зайнятості: запитання та відповіді. Дебит-кредит. №2. 2020. URL: https://news.dtkt.ua/society/community/60967 


\section{References:}

1. Vdovina, G. O. (2011). Analiz ry`nku praci: propozy`ciya ta popy`t na neyi [Labor market analysis: supply and demand for it]. Lviva : LNU imeni Ivana Franka [in Ukrainian].

2. Try`gubenko, V.M. (2020). Adiminstraty`vno-pravovi zasady` realizaciyi derzhavnoyi polity`ky`u sferi zajnyatosti naselennya [Administrative and legal bases for the implementation of state policy in the field of employment]. Extended abstract of candidate's thesis. Dnipro. URL: https://dduvs.in.ua/wp-content/uploads/files/Structure/science/rada31/a2.pdf [in Ukrainian].

3. Yacenko, L.D. (2018) Shhodo priory`tetiv polity`ky`zny`zhennya bezrobittya v Ukrayini [Regarding the priorities of the policy of reducing unemployment in Ukraine]. Nacional `ny $j$ insty 'tut strategichny'x doslidzhen - National Institute for Strategic Studies. URL:http://old2.niss.gov.ua/content/articles/files/1_Zapiska-bezrobittya-YAtsenko-22_12_189b518.pdf [in Ukrainian].

4. Katalog insty`tucij [Catalog of institutions]: Programa «Liderstvo $v$ ekonomichnomu vryaduvanni» - Leadership in Economic Governance Program 2014 - 2017. URL: http://www.lev.org.ua/ua/institutions.html?page=8\&per-page $=15$ [in Ukrainian].

5. Zakon Ukrayiny` «Pro rozvy`tok ta derzhavnu pidtry`mku malogo i seredn`ogo pidpry`yemny`cztva v Ukrayini» vid 22.03.2012 №4618-VI. URL: https://zakon.rada.gov.ua/laws/show/4618-17. [in Ukrainian].

6. Zakon Ukrayiny` «Pro nacional`nu programu spry`yannya rozvy`tku malogo pidpry`yemny`cztva v Ukrayini» vid 21.12.2000 roku №2157-III. URL: https://zakon.rada.gov.ua/laws/show/2157-14\#Text [in Ukrainian].

7. Strategiya rozvy`tku malogo i seredn`ogo pidpry`yemny`cztva v Ukrayini na period do 2020 roku - Strategy for the development of small and medium enterprises in Ukraine for the period up to 2020: rozporyadzhennya Kabinetu Ministriv Ukrayiny` vid 24 travnya 2017 r. №504-r. URL: https://zakon.rada.gov.ua/laws/show/504-2017-r [in Ukrainian].

8. Nakaz Ministerstva social`noyi polity`ky`Ukrayiny` «Pro zatverdzhennya Polozhennya pro derzhavnu sluzhbu zajnyatosti» vid 14.06.2019 №945. URL: https://zakon.rada.gov.ua/laws/show/z0733-19\#Text [in Ukrainian].

9. Derzhavny`j centr zajnyatosti. Oficijny`j sajt. URL: https://www.dcz.gov.ua/

10. Vlasny`j biznes za spry`yannya sluzhby`zajnyatosti: zapy`tannya ta vidpovidi [Own business with the assistance of the employment service: questions and answers]. (2020) Deby`t-kredy`t - Debit credit, 2. URL: https://news.dtkt.ua/society/community/60967 [in Ukrainian]. 